\title{
Hogyan tervezzük meg közösen? Kisgyermekes anyák munkaerőpiaci visszatérésével kapcsolatos vállalati attitüdök
}

$\mathbf{F}$

0

\section{Madai Krisztina}

Az Infonia Alapítvány nói munkaerô-piaci szakértôje. A Budapesti Közgazdaságtudományi Egyetemen, majd a Hageni Távoktatási Egyetemen végzett munkapszichológia és munkapedagógia szakokon. Több civil nói szervezet munkájának támogatója, nemzetközi kutatások résztvevoóje. Az ITTK-Infonia Alapítvány Kismama Reintegrációs Programjának résztvevôje. Elsôsorban a munka és a magánélet egyensúlyának témakörére specializálódott.

E-mail: madai.krisztina@ittk.hu

\section{Így hivatkozzon erre a cikkre:}

Madai Kriszta. „Hogyan tervezzük meg közösen? Kisgyermekes anyák munkaerőpiaci visszatérésével kapcsolatos vállalati attitüdök”. Információs Társadalom VIII, 1. szám (2008): 89-98.

A folyóiratban közölt müvek

a Creative Commons Nevezd meg! - Ne add el! - Így add tovább! 4.0

Nemzetközi Licenc feltételeinek megfelelöen használhatók. 


\section{KUTATÁSI JELENTÉS}

Madai Kriszta

\section{Hogyan tervezzük meg közösen? Kisgyermekes anyák munkaeró-piaci visszatérésével kapcsolatos vállalati attitúdök}

Összefoglalónkban az I'TTK-Infonia Alapítvány által 2007 nyarán a nók munkaerô-piaci reintegrációjának gyakorlatára és az atipikus munkaformák elterjedésére vonatkozóan végzett kutatás eredményeit mutatjuk be. ${ }^{1}$

A kutatás keretében 30 cég felsố vezetôivel (HR-vezetókkel, szervezetfejlesztési vezetókkel, cégvezetókkel) készítettünk strukturált mélyinterjúkat. A cégek kiválasztásában nem volt lehetôségünk a teljes magyar munkaerôpiacot jellemző reprezentatív mintavételre. ${ }^{2} \mathrm{Az}$ interjúk fớ célja az volt, hogy a nók általános munkaerô-piaci helyzetének ismeretén túl képet kapjunk arról, hogy az adott piaci környezetben a vállalatok milyen stratégiát választanak a nối munkaerố foglalkoztatására (különösen a gyermekkel rendelkezố nók esetében), továbbá ott, ahol léteznek atipikus munkaformák, hogyan értékelik az ezekkel kapcsolatos tapasztalatokat a munkaadók (különösen a kisgyermekes munkavállalók tekintetében). Az interjúk eredménye alapján célunk egy valós igényekre és valós lehetôségekre épülố munkaeró-piaci reintegrációt támogató rendszer kidolgozása, mely figyelembe veszi mind a munkaadók, mind pedig a munkavállalók szempontjait.

\section{A szülési szabadság}

A szïlési szabadság jelenlegi rendszere sok esetben nem kedvez a munkaadónak, de a munkavállalónak sem.

A nemzetközi szakirodalom egyre ellentmondásosabban ítéli meg a hosszú távú szülési szabadság rendszerét. Magyarországon ráadásul a hároméves gyes gyakorlatát az elốzố rendszerból emelték át (ahol egyik fontos funkciója az volt, hogy a teljes foglalkoztatás ideája mellett nagyobb mennyiségú munkaerốt tartson távol a munkaerốpiactól) egy meróben eltérô piaci környezetbe. A jelenlegi rendszerben a hosszú távollét

${ }^{1}$ A kutatás a HEFOP-1.3.1-05/1-2005-09-0115/2.0 projekttámogatás keretében valósult meg.

${ }^{2}$ Az interjúkban 27 budapesti és 3 Budapesten kívüli cég munkatársait kérdeztük meg. A felkeresett cégek közül három 50 fönél kevesebbet foglalkoztat, hét 50-100 fö közötti, tizennégy 100-1000 fó́ közötti és hat 1000 fö fölötti foglalkoztatotti létszámmal rendelkezik. A megkérdezett cégek 70\%-a végez szolgáltatást, 10\%-ukban folyik gyártás, $40 \%$ végez kereskedelmi tevékenységet. Az interjúalanyok nemi megoszlása $50-50 \%$ volt. 
után nehéz a visszatérés, de az éles versenyben, egy gyorsan változó piaci környezetben a vállalati oldal számára is nehézséget jelenthet a kiesố munkaerô bizonytalan ideig való pótlása. A kutatás során szerzett tapasztalataink is igazolják, hogy a vállalati oldalon a legnagyobb nehérségek a kisebb cégeknél, a kevésbé prosperáló piaci környezetben tevékenykedő és a létszámalapú elszámolási rendszerben dolgozó vállalatoknál jelentkeznek. „A helyettesítót határozatlan idốre veszik fel, az ő tudása jobb lesz, bedolgozza magát, félnek, hogy a kismama nem fogja bírni már a terhelést, így megköszönik, és valahogy megválnak tóle" (VI17). Elvi megoldásként elhangzott a munkaeró kölcsönzése, ebben a formában lehetséges a helyettesítő munkaerố foglalkoztatása azzal a megkötéssel, hogy a szerződés addig él, míg a kismama vissza nem tér.

Általánosan nagy gondot okoz, hogy mindkét fél részéról nagy a bizonytalanság a visszatérés idejét és az utána vállalt munka mennyiségét és minôségét illetôen. Mindkét fél részéról sok a negatív tapasztalat és az elóítélet a másik hozzáállását tekintve: a cégek sokszor a lehetôségeiken belül sem támogatják az anyákat, illetve az anyák jogosan érzik úgy, hogy a cég foglalkoztatási politikája kirekesztő a kisgyermekesekre nézve, másrészt az anyák gyakran a cégek nyitottsága esetén sem partnerek a szülési szabadság idejére vonatkozó közös stratégia kialakításában.

Sok esetben a cég és a passzív kismamaállomány egymástól teljesen függetlenül létezik; a cég elfelejtkezik a kismamáról, a kismama nem keresi a kapcsolatot a céggel. Vagyis a cégeknek nagy szerepe van abban, hogy a kismama úgy menjen el a szülési szabadságra, hogy érezze, a cég visszavárja, „nem írja le”, partnerként támogatja a visszatérését - ha lehetôség és igény van rá, rugalmasabb keretek között. Az anyáknak pedig nagy a felelósségük abban, hogy ók is éreztessék a munkaadókkal, hogy jelen kívánnak maradni a cég életében, még ha egy átmeneti idớre más minốségben és formában is.

A szülési szabadságnak és az azután következó éveknek a foglalkoztatás szempontjából ideális esetben olyan átmeneti idôszakot kellene jelenteniük, amelyben a gyermekek életkorának és számának (azaz az otthoni feladatok mértékének) függvényében változik a nók keresố munkával és otthoni munkával töltött idejének aránya (egyénileg változó mértékben). Fontos, hogy a nói munkavállalást is folyamatában tekintsék mind a foglalkoztatók, mind pedig az érintett anyák, hiszen ez a szemléleti különbség önmagában egész más hozzáállást eredményezhet. Magyarországon hatványozottan igaz, hogy jelentős mennyiségú jól képzett, szakmai tapasztalattal rendelkezố munkaerố hever parlagon akkor, amikor nem nyílik megfelelő forma a nók családalapítás utáni visszatérésének támogatására.

\section{2. Átmeneti távollét vagy kilépés}

„A cégek a gyermeknevelésre fordított idôt értéktelen, a munkaerôpiac szempontjából kieső idóként tartják számon. Az egyik vezetô megfogalmazásában a cégek ma a kismama szülési szabadságra való távozásakor alapvetően azzal számolnak, hogy az anya nem tér vissza többet dolgozni, így a szülés egyenértékúvé válik a kilépéssel" (VI6).

Ha végiggondoljuk ennek a szemléletnek a következményeit, ez a hozzáállás önmagában is igen megnehezíti, hogy mindkét fél számára kielégítő megoldást találjanak az anyák visszatérésére. Ha a cég nem számít az anyára, az anya (jogosan) nem keresi a 
kapcsolatot a céggel. Ha az anya nem keresi a kapcsolatot a céggel, a cég (jogosan) úgy gondolja, nem számíthat az anyára mint megbízható, jól teljesítő munkaerőre. „Mivel az anyák a szülési szabadság alatt nem kapnak semmit a cégtôl Magyarországon, passzívvá válnak. És ha, mondjuk, két gyermek után vissza akar térni, nincs ember, aki emlékezne rá" (VI17).

Itt utalnék arra a korábban ismertetett kutatási eredményre, miszerint a magyar társadalom igen hagyományos felfogással rendelkezik a nemi szerepekról, ezen belül a nók anyasággal kapcsolatos feladatairól. Ez a társadalmi nyomás nagymértékben megnehezíti, hogy a nók ebben az érzelmileg amúgy is nagy változásokkal járó időszakban világos képet nyerjenek arról, valójában hogyan képzelik el az új helyzetben a helyüket és a szerepüket, illetve a munka szerepét és helyét az életükben. Pedig a nók világos karrierképe, öntudata alapvetốn fontos ahhoz, hogy a szülés után sikerrel tudjanak visszatérni a munkaerôpiacra.

\section{Rugalmatlan szabályozási rendszer}

A jelenlegi szabályozás nehezen illeszthetó be más-más szervezeti kultúrával rendelkezó, eltéró piaci környezetben tevékenykedó cégek foglalkoztatási politikájába, hiányoznak az alternativák, hiányzik a szabályozís rugalmassága.

A közvélemény-kutatások adatai alapján a szülési szabadságon lévố nóknek csak mintegy $40 \%$-a reméli, hogy a korábbi munkahelyére térhet majd vissza. Valójában a visszatérés lehetôsége ágazatonként igen eltérố, sok esetben a cég megszúnik a visszatérés idejére, a különbözố céges kultúrákban eltérố a munkavállaló céghez való kötốdésének mértéke.

Az interjúk alapján elmondható, hogy az SMCG-cégekhez szinte lehetetlen a mai rendszerben visszakerülni.

Érdekes módon van még olyan nagyvállalat is, ahol ezzel szemben megmaradt a „régi rendszer”, vagyis a cégen belüli előmenetel és a juttatások a cégnél eltöltött évek függvényében alakulnak, és az elért pozíció például a leépítéseknél is számít, így az a helyzet áll eló, hogy a hosszú távú szülési szabadságról visszatérốknek nagyon kedvezó a helyzetük, amit a cég megítélése szerint a kismamák igencsak kihasználnak.

Munkáltatói szinten megfogalmazódott az a vélemény is, hogy abban az esetben, ha valaki a hosszú távú otthon maradást választja, nem feltétlenül szerencsés a korábbi munkahelyre visszatérni. Ilyenkor marad a (kényszer)vállalkozások indítása, reálisan ugyanis nehéz elképzelni, hogy ma egy többgyermekes anya hosszabb munkaeró-piaci távollét után a formális munkaerópiacon állást találjon magának (rugalmas feltételekkel).

\section{Vállalati reintegrációs stratégiák}

A cégek nagy részénél mostanában meriilt fel a kismamakérdés tudatosabb kezelésének igénye, kiforrott stratégia a szülési szabadságon lévớállománnyal és a visszatérók reintegrációjával kapcsolatban azonban még csak kivételként jelenik meg. Az erre való igényt nagyon kïlönbözöen értékelik az egyes cégek. 
A kismamákkal való formális kapcsolattartás - eltekintve az adminisztratív jellegú kapcsolattartástól - csak néhány cégnél jelenik meg stratégiaként. Ez utóbbi esetekben felismert, kimutatható gazdasági érdeke kötődik a cégnek ahhoz, hogy megtartsa a már korábban bevált, alkalmasságát bizonyított és az adott céges kultúrát ismerô munkaerôt.

A visszaintegrálás kérdésének kezelését alapvetốn a következố tényezók határozzák meg:

1. a cég szervezeti kultúrája (erôteljes különbségek érzékelhetốk a különböző anyaországú nemzetközi cégek szemlélete és gyakorlata között),

2. a piaci, illetve a gazdasági szükségszerúség,

3. az egyes vezetók személyes érintettsége.

Van olyan cég, ahol a kismamák visszailleszkedését ugyan nem támogatja külön program, azonban nagyon kiforrott, rugalmas beillesztési és folyamatos karriertámogató programmal rendelkeznek, ami tökéletesen adaptálható a kismamák reintegrációja tekintetében. Véleményünk szerint az általános támogató szervezeti kultúra nagyon pozitív fejlődési út, hiszen éppen azt segíti elő, hogy a kismamák helyzetét nem elszigetelten, nem problémaként, nem egyedi esetként kezeli a cég, hanem a kismamák munkaerô-piaci szereplése ugyanolyan normalitásként beleillik a képbe, mint amennyire a ma uralkodó, rugalmatlan teljes munkaidős foglalkoztatás.

Azokban az esetekben, ahol az anyák szülés utáni visszatérése céges érdek, a vállalatok meglepóen pozitívan nyilatkoztak arról, hogy mennyire nem okozott problémát a várandósság alatti munkavégzés és a visszatéréskori rugalmas beosztású munkavégzés átszervezése. Általában a közvetlen munkatársak között kölcsönösségi alapon minden esetben átcsoportosítható a munka szükség esetén. Ez a fajta összjáték csak növeli a csoportokon belüli összetartást és a munka hatékonyságát. Sớt, olyan álláspont is megfogalmazódott, hogy a „kismama-fluktuáció” pozitív hatással volt a cég munkájára, mintegy természetesen biztosítva az állandó megújulás lehetốségét (VI13).

Az olyan szervezeti kultúrákban, ahol belső előrejutási rendszer van, különösen nagy akadályt jelent a nók átmeneti időre való kiválása. Mivel a cég teljes szervezeti kultúrája erre a belsố elốrejutási rendszerre épül, a visszatéró kismama „,nem illik bele a képbe”, nem rendelkezik már az adott pozícióhoz szükséges belsơ hálózati ismeretekkel, túl idôs az adott környezethez stb.

\section{Reintegráció: szociális kérdés vagy gazdasági érdek?}

A kismamakérdést sem a munkáltatói, sem pedig a munkavállalói oldal nem tekintheti csupán szociális kérdésnek. Nyilvánvaló, hogy a közös érdeket a munkaeröpiacon csakis gazdasági alapokon lehet megtalálni.

Mindaddig, amíg a munkáltató csupán szociális, illetve társadalmi kérdésnek tekinti az anyák foglalkoztatását, nem várható valós elôrelépés a kérdésben. Ha a társadalmi problémák kezelése nem jár együtt anyagi érdekekkel, elóbb vagy utóbb kudarcba fog fulladni minden ilyen irányú törekvés. Az elooző elemzések alapján nem nehéz megfejteni, mi áll annak a hátterében, hogy a munkáltatók a kismamakérdést pozitív eset- 
ben is még mindig csupán szociális kérdésnek tekintik. Ahhoz, hogy ez a kérdés változzon, véleményem szerint két lehetséges út vezet: szemléletformálás és állami gazdasági ösztönzók, illetve a munkaerốpiac változása (rugalmasság, munkaeróhiány).

Azok a cégek, ahol már vannak tapasztalatok a nói vezetók (rugalmas) visszaintegrálásának tekintetében, egyértelmúen pozitív eredményekról számolnak be:

- megtakaríthatók a fejvadászköltségek,

- csökken a kockázat, hiszen már korábban bevált munkaerốról van szó,

- nố a munkavállalói lojalitás,

• nố a munkavállalói elkötelezettség.

\section{Mentálhigiénés támogatás}

A gyermekvállalás utáni visszatéréssel járó mentálhigiénés nehézségek tudatossága nagyon alacsony, e problémák kezelését senki nem vállalja magára.

Itt szeretnénk utalni arra, hogy a kismamák körében végzett felmérésünk szerint a kismamák maguk sem tudatosítják azokat a mérhetetlen változásokat, amelyek egy gyermek (legfóképp az elsố gyermek) születésekor fellépnek, és amely változások jelentôsen befolyásolják az anyák munkaerôpiacon való megjelenését és ennek formáját. Márpedig mindaddig, amíg ezek a kérdések nem tematizálódnak, ez a sikeres reintegráció kerékkötốjévé válik. Megítélésünk szerint amennyiben a cégek felismerik, hogy számukra valós gazdasági érdek a jó munkaerố megtartása, akkor realitássá válhat az effajta problémák kezelésében nyújtott támogatás. A mai magyar társadalomban rengeteg tényezố nehezíti a tudatosság kialakítását, így a vállalatoknak is fontos társadalmi szerep juthat e feladat megoldásában.

\section{A szervezeti kultúra és a reintegráció összefüggései}

Az adott cégek szervezeti kultúrája (ezen beliul kiemelten az anyacégtól átvett kulturális minta) nagymértékben befolyásolja a nók reintegrációjával kapcsolatos céges stratégiát.

Az interjúk során érdekes volt megfigyelni, hogy mennyire alapvetố befolyással van a szervezeti kultúrára az anyacég nemzeti hovatartozása. Az amerikai cégeknél jellemzốen nagyon tudatos és magas fokú a diszkrimináció elkerülését célzó stratégia alkalmazása, de ezzel párhuzamosan sok esetben erốs az a szemlélet is, miszerint „mindenki a maga sorsának kovácsa”. Így tehát a nối munkaeró helyzetére vonatkoztatva mind a kiválasztás, mind a belső elôrejutás során kerülik a diszkriminációt (várandósan is el lehet menni felvételi beszélgetésre, a várandósság önmagában nem lehet oka a felvétel elutasításának), a szülés kapesán pedig biztosítják a rugalmas visszatérés lehetôségét. Ezek a cégek azonban kevésbé tekintik feladatuknak, hogy aktívan felkarolják a munkavállalókat, és segítsék óket a visszailleszkedésben. Saját karrierjük tudatos tervezését, a saját életproblémáikkal való szembenézést és ezek kezelését a munkavállalóktól várják el.

A magyar cégeknél sajnos a rejtett diszkrimináció számos megnyilvánulásával szembesültünk az interjúk során is. Számtalan nemi sztereotípia él a munkaadók fejé- 
ben, melyekkel kapcsolatban nem is tudatosul bennük ezeknek a munkavállalásra gyakorolt diszkriminatív hatása. Az interjúk során - a legnagyobb jóindulattal - számos sztereotípia hangzott el a „nói képességekról”, a nók igényeirôl, a nók szerepéról.

\section{Az igénybe vett szülési szabadság hossza}

A szülési szabadságról való visszatérés ideje cégenként igen eltéröó, az egyes cégeken beliil viszont viszonylag egységes mintát mutat.

Itt valószínúsíthetốen több tényezố egymásra hatásának eredménye az a döntés, amely alapján a kismamák a visszatérésüket szervezik. Egyértelmúen ilyennek túnnek a kereseti lehetóségek, illetve a cég nyitottsága a munkaeró megtartására. Feltételezhetốaz is, hogy a szervezeti kultúra már a kiválasztáskor szelekciós erővel bír, így a munkával (és családdal) kapcsolatosan eltéró értékrendekkel kerülnek be a munkavállalók a különbözố típusú szervezetekbe. Ahhoz, hogy a nók döntéseiról pontos képet kaphassunk, nagyon érdekes lehet egy-egy vállalat esetében a vállalati kultúrát és - a munkastruktúrák ismeretében - a kismamák személyes döntéseinek hátterét vizsgálni, és e két oldalt összevetni. Valószínúsíthetôen egy-egy tipikusnak tekinthetố vállalat esetében elvégzett átfogó kutatás rengeteg hasznos információval szolgálhat nemcsak az adott vállalatnak, de a munkaerôpiac más szereplóinek is a sikeres reintegráció megvalósításához.

Feltehetố továbbá, hogy minden cégnél kialakul egy minta, amihez aztán a többi anya igazodik döntésében. Erre példa kutatásunkban az a cég, ahol a HR-vezetố elmondta, hogy cégüknél az elsố kismama rugalmas reintegrálása hatalmas nehézségekbe ütközött, és csak azért lehetett sikeres, mert a kismama nagyon jó munkaeró volt, nagyon motiváltan és tudatosan lépett fel, és szükség volt a HR-vezetô maximális támogatására is. Miután ez a „mintaprojekt” pozitív eredménnyel zárult, a késóbb szülni készülő kismamák már e minta alapján alakították ki saját elképzeléseiket (VI11).

\section{Nőkérdés vagy közös társadalmi-gazdasági probléma?}

Az interjúk során minimális mértékben meriilt fel a: a szemlélet, miszerint a férfiaklapák foglalkoztatásában is változásokra lenne szükség.

A férfiak részéról feltúnó, hogy bár a saját családi tapasztalataik alapján a jelenlegi körülmények között egyre többen kétségbe vonják a nók valós esélyeit a visszatérésre, ezt egyidejúleg el is fogadják, kevéssé merül fel a változtatás igénye (fóleg nem olyan áron, hogy ez az ô munkavégzésüket is érintené). Ugyanakkor gyakran tapasztalható, hogy a férfiak erốs családcentrikussága együtt jár a hagyományos feladatmegosztás támogatásával, és ez nagymértékben nehezíti a valós nemi esélyegyenlốség kialakulását. A legtöbb férfi felsô vezetô a karriert és a családot összeegyeztethetetlennek tartja.

Többször történt utalás arra is, hogy a nók helyzetét illetốen alapvetố hatású, hogy a döntéshozó szervekben nagyon alacsony a nók aránya, illetve vidéken túlnyomórészt az idôsebb férfi generáció kezében van a döntés (akik egészen más környezetben szo- 
cializálódtak), Budapesten pedig nagy arányban vannak fiatal, nem családos férfiak döntéshozói pozíciókban (akik még nem rendelkeznek sem személyes, sem pedig szakmai tapasztalatokkal a kérdést illetôen).

\section{Versenyelőny megteremtése a rugalmas munkaformák bevezetésével}

Jelenleg a rugalmas munkaformák felévaló nyitás azon cégek esetében figyelhetó meg, ahole lehetöségben látják a cég versenyelönyének bi:tositását.

Mivel a fejlettebb ipari országokban halmozódtak fel ellentmondásos tapasztalatok a nók részmunkaidóben való munkaerố-piaci reintegrációjával kapcsolatban, tulajdonképpen örvendetes jelenség, hogy a távmunka lehetôsége ma Magyarországon nem kapcsolódik össze közvetlenül a kismamakérdéssel. Tekintve a munkaerópiac szegregációját, csak így érhető el az, hogy a távmunka is egyenrangú munkaformává válhasson, megfelelố presztízzsel, megfelelő juttatásokkal, és ne ütközzön belsố ellenállásba a szervezeteknél. Jelenleg ugyanis megfigyelhetố, hogy a kollégák ferde szemmel néznek arra, aki „korábban hazamehet”, az otthon végzett munka nem látványos, ezért úgy tekintenek rá, mintha nem is létezne. Több jelenleg használatos teljesítményértékelő rendszer meghatározó modulja a kollégák véleménye: ahhoz, hogy ez a távmunkára adaptálható legyen, a távmunkát megfelelően kell integrálni a szervezetbe, biztosítani kell a szükséges, a korábbi gyakorlattól eltérố kapcsolatokat, kommunikációs csatornákat és módokat.

Sok esetben elhangzott, hogy azok a cégek, amelyek biztosítják valamilyen formában a rugalmas munkavégzés lehetőségét, ezt csak abban az esetben teszik, ha a munkaerố korábban normál munkaviszonyban dolgozott a cégnél, és ilyen módon bizonyított már. (Gyakran ezekben az esetekben is csak átmeneti, lehetóleg minél rövidebb ideig, és már ez az átmeneti szakasz is hatalmas privilégiumnak számít!)

Ebból következốen ha egy nó olyan cégtớl megy szülési szabadságra, ahol nincs rugalmas munkavégzési lehetôség, a formális munkaerôpiacon késóbb erre vajmi kevés esélye van.

\section{Szemléletváltás a munka világának rugalmasabbá tétele érdekében}

A sikeres távmunka meghonosodásához komoly szemléleti váltásra van sziikség mind a munkáltatói, mind pedig a munkavállalói oldalon.

Itt nemesak arról van szó, hogy a munkáltatóknak nyitottabbá kellene válniuk a munka új strukturálására, hanem arról is, hogy a távmunka egészen újszerú fónök-beosztotti viszonyt igényel, más kommunikációs eszközökkel és rutinokkal, a jelenlegi gyakorlattól eltérő célmeghatározásokkal és teljesítményméréssel.

A munkáltatók gyakorlata szerint nemcsak a merev céges struktúrákkal van baj, amit nehéz feltörni, de a munkavállalókkal is, akik nem nóttek még fel a rugalmas foglalkoztatás feladatához. Gyakran még a kommunikáció megszokott formáival is jelentős 
problémák vannak, nincs meg az alapvetố bizalom. Egy interjúalany megfogalmazásában: „E tekintetben a nók még nagyobb lemaradásban, hátrányban vannak, mivel önbizalomhiánnyal küszködnek, egy eleve diszkrimináló rendszerbe, struktúrába kellene beilleszkedniük" (VI14).

A szemléletváltást nehezíti, hogy a munkaeróbe való befektetés a hosszú távú tervezés része, ami a mai magyar gazdasági helyzetben kevésbé jellemzó: a cégek számottevố része pár éves múködés után megszúnik, vagy kivonul a magyar piacról.

\section{A magyar munkakultúra és a rugalmas munkaformák ütközőpontjai}

A magyar munkakultúra jelenlegi gyakorlata igencsak megnehezíti a rugalmas munkaformák, fóleg a távmunka terjedését: gondok vannak a bizalom, a kommunikáció és a munka ellenốrizhetôségének kérdéskörével.

Ma Magyarországon sok vezetô elmondása alapján nem a teljesítményt és a tudást fizetik meg, hanem a munkahelyen töltött idôt. A vezetóképzés nem alkalmazkodott a munkaerőpiac új igényeihez, a vezetók gyakran nem képesek valós célokat megfogalmazni, fóleg, ha nem számszerú, hanem minóségi célokról van szó. Ebból adódóan nehéz a teljesítmény mérése, amit legegyszerúbben a munkahelyen töltött órák ellenôrzésével lehet áthidalni. Másrészt rengeteg a negatív tapasztalat a munkaadói oldalon a munkavállalók moráljával és teljesítményével kapcsolatban.

Gyakran említették a cégvezetók, hogy még ha elvi lehetôsége van is a rugalmas munkaformák megvalósításának, a munkavállalók részéról kicsi az igény erre. Érdekes lenne vizsgálni az e mögött a jelenség mögött álló okokat. Feltehetốen a következó tényezóknek lehet ebben szerepe: anyagi indokok, állásvesztéstốl, pozícióvesztéstốl való félelem (ha nincs állandóan jelen, ,kiesik a pikszisból”), a tapasztalat, a gyakorlat és a bátorság hiánya a saját igények aktív képviselete terén, másoktól hallott negatív tapasztalatok kivetítése. Ugyanakkor nem tekinthetünk el attól sem, hogy a munkavállalók sok esetben nem kívánják felvállalni az önálló munkavégzéssel járó felelôsséget sem.

\section{Jogszabályi keretrendszer}

A rugalmas foglalkoztatás és a rugalmas reintegráció jogsæabályi keretei általában kevéssé ismertek, sok az ezekkel kapcsolatos bizonytalanság, nincs igazán fórum, ahonnan a cégek ez ïgyben segitséget kaphatnának.

Sok esetben a cégek inkább a biztos megoldást választják, még akkor is, ha ez az anyának (vagy éppen mindkét félnek) rosszabb. Gondot okoz például a gyed alatti „bedolgozás" kifizetése (egy-egy alkalmi projektért nyilván nem éri meg a kismamának visszamondani a gyedet, ugyanakkor éppen ezek az eseti munkák biztosíthatják azt, hogy a kismama benne maradjon a szakmai munkában, a céges vérkeringésben), valamint a szülési szabadság egésze alatt felhalmozott évi rendes fizetett szabadság kiadásának időzítése. 


\section{A reintegráció támogatásának lehetőségei}

A reintegráció támogatása szempontjából fontos kérdés, hogy a szóban forgó célcsoport tagjai eredeti munkahelyiikre kivánnak-e, illetve tudnak-e visszatérni, vagy pedig új állást, új munkahelyet keresnek. E két forma egészen eltérö helyzet, így eltérö támogatást igényel.

A nók munkaerô-piaci visszatérését támogató program középpontjába a nók tudatos karriertervezésének támogatását kell helyezni. Ennek megvalósításához a nôket szembesíteni kell a személyes döntéseikre befolyást gyakorló munkaerố-piaci struktúrákkal és a valós választási lehetôségekkel, a munkaerôpiac elvárásaival, a saját érdekeik képviseletéért való kiállás fontosságával és ennek módszereivel. Segíteni kell az anyákat, hogy olyan, értékeiket és érdekeiket ismerő, öntudatos munkavállalókként jelenjenek meg a munkaerốpiacon, akik ismerik saját lehetôségeiket és képességeiket, ezeket képesek kommunikálni és ók maguk sem „támogatandónak” érzik magukat!

A kutatás alapján elengedhetetlennek túnik a „kismamák” különböző csoportjainak módszeres elkülönítése, helyzetük eltéréseinek feltérképezése, amire az esetleges támogatás egyedi formáit építeni lehet.

Szintén elengedhetetlen a minóségi, az anyák munkaerô-piaci elkötelezettségeihez igazodó gyermekellátó rendszer támogatása.

\section{Összefoglalás}

A fejlett ipari országokban az egyre inkább jellemző munkaeróhiány enyhítésének legfontosabb eszköze a nók munkavállalása.

Nemzetközi kutatások egyértelmúen bizonyítják, hogy azokban az országokban, ahol sikerült a nóket nagyobb arányban foglalkoztatni, számottevốen nótt az ország GDP-je. Azokban az országokban pedig, ahol segítették a nói vállalkozások elterjedését, ez még az elơzônél is nagyobb arányú GDP-növekedést okozott. Magyarországon a nók munkaerốpiaci részvételének támogatásán túl szükség van egy mélyebb kulturális váltásra és az állami családtámogatási rendszer átgondolására.

A nói esélyegyenlőséggel kapcsolatban az egyik legfontosabb feladat a nói és a férfiszerepek újragondolása. Mivel az idómérleg-vizsgálatok sorra kimutatják, hogy a nók a fizetett és a fizetetlen munka összességét tekintve jelentôsen többet dolgoznak a férfiaknál, a nók munkájának gazdaságilag és társadalmilag elismert értéke azonban alatta marad a férfiakénak, megoldást kell találni a fizetetlen munka elismerésére és a nók egyenlő esélyekkel való munkaerô-piaci integrációjára. Ezen túl az a hozzáállás, hogy a gyermeknevelést a társadalom hobbinak tekinti, súlyos diszkrimináció forrása a gyermektelen nókkel és férfiakkal szemben. Az eloórelépést ezekben a kérdésekben a munkaerôpiac fejlódése mellett az ismert demográfiai problémák is sürgetik.

Mindaddig, amíg a munkaerôpiacon a férfiakra jellemzó foglalkozási gyakorlat jelenti a normát, a nốk helyzete problematikus marad. Amíg a teljes idốs foglalkoztatás a norma, addig a részmunkaidóben végzett munka és a távmunka alacsonyabb rendú marad. Általános célnak kell tehát lennie a munkaidố rugalmasabbá tételénk, ami elôsegíti, hogy a férfiak munkaideje is összeegyeztethetố legyen az otthoni feladatokkal. 
A fejlettebb ipari országok a gazdasági fejlettség azon szintjén állnak, ahol a legtöbb vállalat számára az üzleti érdek megvalósítása a munkavállalók személyes érdekeinek figyelembevétele nélkül egyre kevésbé oldható meg. Magyarországon ez a tendencia még csak a legélesebb versenyhelyzetben múködớ, túlnyomóan magasan kvalifikált munkavállalókat foglalkoztató cégeknél figyelhetố meg. Ahhoz tehát, hogy mindezen változások a munkaerốpiacon valóban bekövetkezzenek, szükséges az állami szerepvállalás (a reintegráció ösztönzése, a szociális és munakerő-piaci struktúrák összehangolása, a jogszabályok egységesítése és egyszerúsítése, s ezek megfelelố ismeretének biztosítása), a társadalmi tudatosság szintjének növelése és a prevenciós szemlélet elterjedése. 